Apidologie, 1981, $12(2), 125-132$.

\title{
AMINO ACIDS IN THE FLORAL NECTAR OF COTTON
}

\author{
Martha GILLIAM (*), W. F. Mc CAUGHEY (**) and Joseph O. MOFFETT $\left({ }^{* * *}\right)$
}

\begin{abstract}
SUMMARY
The free amino acids in the floral nectar of three cultivars of cotton (Gossypium spp.) were determined with an amino acid analyzer. Only four amino acids (aspartic acid, serine, threonine and glutamic acid) were found in nectar of Deltapine 16 and A-line Stoneville 213 cultivars grown at one location. These amino acids were also the predominant ones in the nectar of Deltapine 61 grown at another location. Nectar from Deltapine 61 contained 14 of the 17 amino acids that the analytical techniques used were capable of detecting. Only cystine, methionine and tyrosine were not present.

Amino acids in nectar from plants sprayed twice with various levels of the herbicide 2,4-D fluctuated with both time and treatment. In addition, the overall quantity of nectar amino acids per flower increased in treated plants of all cultivars since spraying with 2,4-D increased the volume of floral nectar by more than $30 \%$ in some cases.
\end{abstract}

\section{INTRODUCTION}

BAKER and BAKER (1973 a, 1973 b, 1975, $1976 \mathrm{a}, 1976 \mathrm{~b}, 1977)$ and BAKER et al. (1978) examined the floral nectar of over 1,000 species of flowering plants for amino acids and concluded that the occurrence of free amino acids in nectars is probably universal among nectariferous flowering plants and that the amino acids are present in a characteristic pattern in any particular species. They also pointed out that nectar amino acids may be important in the nutrition of the flower visitor as well as contributing to taste and the feeding stimulus, although the amounts are small in

(*) Agric. Res., S.E.A., U.S.D.A., Carl Hayden Bee Research Center, 2000 E. Allen Road, Tucson, AZ 85719.

(**) Department of Nutrition and Food Science, University of Arizona, Tucson, AZ 85721.

(***) Agric. Res., S.E.A., U.S.D.A., Oklahoma State University, 501 Life Sciences West, Stillwater, OK 74074. 
comparison to the concentration of sugars. Usually alanine, arginine, serine, proline and glycine are the most common amino acids in nectar (BAKER et al., 1978). Butterfly-pollinated flowers seem to produce nectar containing higher concentrations of amino acids more consistently than do bee-visited flowers, a difference attributed to the utilization by bees of pollen as an alternative source of amino acids.

To our knowledge, the amino acids in the floral nectar of cotton (Gossypium spp.) have not been determined, although CLARK and LUKEFAHR (1956), using paper chromatography, failed to find amino acids in Gossypium extrafloral nectar. However, Mound (1962) detected two ninhydrin-positive substances on paper chromatograms of extrafloral nectar from G. barbadense L., and HANNY and ELMORE (1974), using both gas and thin layer chromatography, found 24 free amino acids in extrafloral nectar of G. hirsutum L. Yоконама (1978), without giving data, stated that she found a high concentration of amino acids in extrafloral nectar of $G$. hirsutum.

BAKER et al. (1978) examined 21 species of tropical- and temperate-zone flowering plants and found that extrafloral nectar had a different amino acid complement from floral nectar even when both were produced on the same plant. They stated that this difference was not surprising since floral and extrafloral nectars feed a different range of animals, pollinators at the flowers and often ants and wasps at the extrafloral nectaries. Certain amino acids, particularly the cysteine group, lysine, asparagine and tyrosine, are more frequently represented in extrafloral nectars than in floral nectars.

In many areas, cotton is considered a major honey plant. Moreover, cotton is benefited by bees by greater lint and seed production, decreased time for harvest, fewer motes, better lint, and improved qualities in the offspring (McGREGOR, 1976). Honey bees are probably the insect species that will be used in most cases to pollinate the male sterile flowers in the production of hybrid cotton seed. Even though honey bees visit cotton flowers primarily to collect nectar and rarely collect cotton pollen, the pollen grains adhere to the hairs of the bees collecting nectar and are transferred to the stigma of the flower; thus, they are effective pollinating agents of cotton. MoFFETT et al. (1978) showed that floral visits by honey bees resulted in increased boll set, heavier bolls, more seeds per boll and more cotton seed per flower.

Therefore, because of the importance of floral nectar in attracting honey bees to the flower for pollination, we analyzed the nectar of three cultivars for amino acids. Also, since MoFFETT et al. (1980) found that spraying small concentrations of 2,4-D increased the volume of floral nectar of several cotton cultivars in Arizona, we also analyzed nectar from cotton plants sprayed with 2,4-D that were used by them.

\section{MATERIALS AND METHODS}

Details of procedures used to spray cotton plants and collect floral nectar are given by MoFFETT et al. (1980). Briefly, the amine form of 2,4-D was applied at the rate of 187 liters per hectare. In 1975, two 
cultivars of cotton growing on the University of Arizona Agricultural Experimental Farm at Marana were sprayed with 2,4-D applied in 4 concentrations $(0.01,0.1,1.0$ and $10 \mathrm{ppm})$ on June 23 and July 14 . One of the cultivars sprayed was Deltapine 16 (G. hirsutum L.) and the other was an A-line Stoneville 213 containing cytoplasm from $G$. harknessii BRANDEgeE. This genotype was developed by Lee Stith of the University of Arizona from the male sterile Deltapine 8 stock with $G$. harknessii cytoplasm released by MeYer (1973). Also, on June 24, 1976, one ppm of 2,4-D was sprayed on Deltapine 61 cotton plants that were beginning to flower at Sacaton, Arizona. Matching unsprayed check plots were used in all tests.

All nectar samples were collected from cotton flowers that had been bagged the previous day in the late bud stage. Cotton flowers normally bloom for only one day, opening in the morning and closing in the late afternoon, at which time the petals fold together so that the floral nectar is no longer accessible to the bees. Nectar was drawn from the nectaries into 10- $\mu$ l pipets. All samples were collected after 1 p.m. Mountain Standard Time since the amount of nectar produced by cotton flowers increased in almost a linear manner from a low point at 9:00 a.m. to a peak that occurred about 4:00 p.m. (MoffeTt et al., 1976).

In the 1975 test, nectar samples were collected on July 15, July 22, July 29 and Aug. 22. In 1976, samples were collected on Aug. 12 and 13. All the capillary tubes were sealed with Critoseal (1), placed in vials on dry ice for transport to the laboratory and stored at $4{ }^{\circ} \mathrm{C}$ until analyzed.

Since the protein content of the nectar samples was negligible as determined by the microkjeldahl technique (KIRK, 1950), hydrolysis was unnecessary. The samples were weighed in tared centrifuge tubes and a $p \mathrm{H} 2.2$ citrate buffer was added to give a final volume of $2 \mathrm{ml}$ per sample. It was usually not necessary to filter the samples. The free amino acids were then determined on a Beckman Model 121 amino acid analyzer (SPACKMAN, 1963).

\section{RESULTS}

Tables 1, 2 and 3 show the amino acids found in the floral nectar of the 3 cultivars of cotton. Only 4 amino acids (aspartic acid, serine, threonine and glutamic acid) were found in the nectar of Deltapine 16 and A-line Stoneville 213 grown at Marana (Tabl. 1 and 2) and these amino acids were also the predominant ones in the nectar of Deltapine 61 grown at Sacaton. Deltapine 61 nectar contained less ammonia than Deltapine 16 or the A-line. However, nectar from this cultivar contained 14 of the 17 amino acids that our analytical techniques were capable of detecting (Tabl. 3). Only cystine, methionine and tyrosine were absent.

In Deltapine 16 nectar (Tabl. 1), the amount of ammonia generally decreased with increasing concentrations of 2,4-D. Also, the levels of ammonia showed a general decrease with time in both the control and all treatment groups. Glutamic acid was found only in nectar from plants that were treated with $0.1 \mathrm{ppm}$ or higher concentrations of 2,4-D, and threonine was found only in plants treated with 2,4-D with one exception. Fluctuations in aspartic acid levels occurred with both treatment and time and variations were also noted in serine levels. In all cases the levels of ammonia plus amino acids were highest in the control groups and lowest in nectars

(1) Mention of a proprietary product or company name in this paper does not constitute an endorsement of this product by the U.S.D.A. 
TABL. 1. - Percentage amino acids expressed as $\mathrm{mg} \%$ ( $\mathrm{mg}$ per $100 \mathrm{~g}$ of floral nectar) from Deltapine 16 (Gossypium hirsutum L.) cotton. Marana, Arizona, 1975.

\begin{tabular}{l|c|c|c|c|c|c}
\hline \hline \multirow{2}{*}{$\begin{array}{c}\text { Date of } \\
\text { collection }\end{array}$} & \multirow{2}{*}{$\begin{array}{c}\text { Ppm 2,4-D } \\
\left(^{*}\right)\end{array}$} & \multicolumn{5}{|c|}{ Ammonia and amino acids } \\
\cline { 3 - 7 } $7 / 15 / 75$ & 0 & $\mathrm{NH}_{3}$ & Asp & Thr & Ser & Glu \\
\hline & 0.01 & 20.12 & 7.25 & - & - & - \\
& 0.1 & 3.39 & 6.27 & - & 2.21 & - \\
& 1.0 & 2.99 & 5.54 & 0.17 & 2.80 & 0.91 \\
$7 / 22 / 75$ & 10.0 & 2.32 & 12.58 & 0.40 & 5.42 & 1.10 \\
& 0 & 4.23 & 13.32 & 0.16 & 2.34 & 0.46 \\
& 0.01 & 5.55 & 13.59 & - & 5.21 & - \\
& 0.1 & 1.34 & 4.25 & 0.06 & 0.69 & - \\
$7 / 29 / 75$ & 1.0 & 1.39 & 6.18 & 0.42 & 3.06 & 1.40 \\
& 10.0 & 1.24 & 8.39 & 0.43 & 3.50 & 0.73 \\
& 0 & 5.03 & 7.57 & - & 1.00 & - \\
& 0.01 & 2.90 & 7.18 & - & 2.64 & - \\
$8 / 22 / 75$ & 0.1 & 0.96 & 5.18 & - & 0.65 & 0.43 \\
& 1.0 & 0.74 & 7.08 & 0.09 & 0.95 & 0.47 \\
& 10.0 & 0.98 & 6.34 & 0.07 & 1.23 & 0.56 \\
& 0 & 2.61 & 19.96 & - & 1.30 & - \\
& 0.01 & 3.38 & 17.30 & - & 2.72 & - \\
& 0.1 & 0.92 & 9.18 & - & 0.96 & 0.40 \\
& 1.0 & 0.71 & 18.48 & 0.19 & 1.82 & 0.53 \\
& 10.0 & 0.87 & 11.51 & 0.08 & 1.25 & 0.32 \\
\hline
\end{tabular}

(*) Plants were sprayed on June 23 and July 14, 1975.

TABL. 2. - Percentage amino acids expressed as $\mathrm{mg} \%$ ( $\mathrm{mg}$ per $100 \mathrm{~g}$ of floral nectar) from A-line Stoneville 213 (male sterile) cotton. Marana, Arizona, 1975.

\begin{tabular}{|c|c|c|c|c|c|c|}
\hline \multirow{2}{*}{$\begin{array}{l}\text { Date of } \\
\text { collection }\end{array}$} & \multirow{2}{*}{$\begin{array}{c}\text { Ppm 2,4-D } \\
\left(^{*}\right)\end{array}$} & \multicolumn{5}{|c|}{ Ammonia and amino acids } \\
\hline & & $\mathrm{NH}_{3}$ & Asp & Thr & Ser & Glu \\
\hline \multirow[t]{5}{*}{$7 / 15 / 75$} & 0 & 3.55 & 4.59 & 0.62 & 4.92 & 0.86 \\
\hline & 0.01 & 2.72 & 3.83 & - & 1.80 & - \\
\hline & 0.1 & 1.84 & 3.49 & 0.14 & 2.87 & 0.72 \\
\hline & 1.0 & 3.50 & 7.44 & - & 1.12 & - \\
\hline & 10.0 & 5.33 & 3.62 & - & 1.27 & - \\
\hline \multirow[t]{5}{*}{$7 / 22 / 75$} & 0 & 4.43 & 5.58 & - & 1.30 & - \\
\hline & 0.01 & 4.27 & 3.72 & - & 2.56 & - \\
\hline & 0.1 & 3.05 & 4.09 & - & 0.75 & - \\
\hline & 1.0 & 1.40 & 6.33 & 0.14 & 1.25 & 0.38 \\
\hline & 10.0 & 1.47 & 3.58 & 0.11 & 1.75 & 0.52 \\
\hline \multirow[t]{5}{*}{$7 / 29 / 75$} & 0 & 2.22 & 9.63 & - & 1.87 & 0.68 \\
\hline & 0.01 & 2.54 & 7.52 & - & 1.09 & 0.38 \\
\hline & 0.1 & 1.00 & 11.67 & 0.09 & 1.56 & 0.61 \\
\hline & 1.0 & 1.43 & 5.35 & 0.10 & 1.13 & 0.63 \\
\hline & 10.0 & 1.32 & 6.25 & 0.07 & 1.44 & 0.47 \\
\hline \multirow[t]{5}{*}{$8 / 22 / 75$} & 0 & 4.21 & 4.27 & - & - & - \\
\hline & 0.01 & 1.03 & 11.27 & - & 0.79 & 4.38 \\
\hline & 0.1 & 0.98 & 16.15 & 0.19 & 1.99 & 0.49 \\
\hline & 1.0 & 0.94 & 9.81 & 0.08 & 1.16 & 0.42 \\
\hline & 10.0 & 1.39 & 8.79 & 0.14 & 1.81 & 0.71 \\
\hline
\end{tabular}

(*) Plants were sprayed on June 23 and July 14, 1975. 
TABL. 3. - Percentage amino acids expressed as $m g \%$ ( $m g$ per $100 \mathrm{~g}$ of floral nectar) from Deltapine 61 (Gossypium hirsutum L.) cotton. Scaton, A rizona, 1976.

\begin{tabular}{l|c|c|c|c}
\hline \hline \multirow{2}{*}{$\begin{array}{c}\text { Amino acids } \\
\text { and ammonia }\end{array}$} & \multicolumn{3}{|c}{ Date of collection and treatments $\left(^{*}\right)$} \\
\cline { 2 - 5 } & $8 / 12 / 76$-check & $8 / 13 / 76$-check & $\begin{array}{c}8 / 12 / 76-1 \mathrm{ppm} \\
2,4-\mathrm{D}\end{array}$ & $\begin{array}{c}8 / 13 / 76-1 \mathrm{ppm} \\
2,4-\mathrm{D}\end{array}$ \\
\hline Lys & 0.29 & 0.26 & 0.17 & 0.34 \\
$\mathrm{His}$ & 0.20 & 0.22 & 0.20 & 0.24 \\
$\mathrm{NH}_{3}$ & 0.57 & 0.79 & 0.46 & 0.73 \\
$\mathrm{Arg}$ & 0.15 & 0.04 & 0.11 & 0.07 \\
Asp & 27.78 & 21.89 & 24.32 & 2.82 \\
Thr & 0.48 & 0.55 & 0.40 & 0.61 \\
Ser & 5.86 & 5.81 & 4.78 & 5.60 \\
Glu & 1.01 & 1.54 & 0.97 & 1.53 \\
Pro & 0.30 & 0.23 & 0.24 & 0.29 \\
Gly & 0.09 & 0.07 & 0.06 & 0.09 \\
Ala & 0.23 & - & 0.17 & - \\
Cys & - & - & - & 0.21 \\
Val & 0.26 & - & 0.21 & - \\
Met & - & - & - & 0.18 \\
Ile & 0.17 & - & 0.14 & 0.08 \\
Leu & 0.06 & - & - & - \\
Tyr & - & 0.30 & 0.35 & 0.37 \\
Phe & 0.40 & & & \\
\hline
\end{tabular}

(*) Plants were sprayed on June 24, 1976.

from plants treated with $0.1 \mathrm{ppm}$ of 2,4-D. Levels of amino acids minus ammonia fluctuated with both time and treatment.

In nectar from the male sterile A-line cotton (Tabl. 2), trends were less evident because of variability in levels of ammonia, levels of individual amino acids, total amounts of amino acids and total amounts of ammonia plus amino acids. With one exception, threonine was found only in nectar from plants treated with $0.1 \mathrm{ppm}$ or higher concentrations of 2,4-D. Thus, in both cultivars grown at Marana, the levels of amino acids varied both with time and treatment.

Aspartic acid was the predominant amino acid in Deltapine 61 nectar (Tabl. 3) and was present in higher amounts in this cultivar than in either Deltapine 16 or A-line cotton. It comprised approximately $70 \%$ of the total amino acids plus ammonia in the floral nectar. In fact, the three major amino acids (aspartic acid, serine and glutamic acid) made up $90 \%$ of the total found. Much less variation occurred in levels of amino acids and ammonia in Deltapine 61 probably because the floral nectar was sampled on only two consecutive dates and because the treated plants were sprayed only once with $1 \mathrm{ppm}$ of 2,4-D seven weeks before the samples were collected. The largest variations in the nectar occurred in aspartic acid levels of the untreated plants sampled on August 12 and 13, the untreated and treated plants sampled on August 12 and the treated plants sampled on August 12 and 13. Other differences in amino acid 
levels either between untreated plants, treated plants, or treated vs. untreated plants sampled on the same day were $1 \mathrm{mg} \%$ or less.

\section{DISCUSSION}

In contrast to the extrafloral nectar of cotton (HANNY and ELMORE, 1974), the predominant amino acids in floral nectar of the three cultivars from two locations were aspartic acid, serine, glutamic acid and threonine. Of these, only glutamic acid + glutamine was a major amino acid in extrafloral nectar (HANNY and Elmore, 1974). Thus, our data support the contention of BAKER et al. (1978) that extrafloral nectar differs in its complement of amino acids from that of floral nectar.

HANNY and Elmore (1974) found no qualitative differences in amino acids of extrafloral nectar from five cultivars of $G$. hirsutum. However, they attributed the quantitative variations in nectar collected at different times to fluctuations in water content once the nectar is secreted and exposed to the environment. The small quantitative differences in amino acid concentrations of Deltapine 61 may also have been caused by fluctuations in water content. No qualitative differences were found in the amino acids of this cultivar.

Fewer amino acids and more quantitative differences were evident in nectar from Deltapine 16 and A-line Stoneville 213 than in nectar from Deltapine 61. These variations may have been caused by environmental conditions, cultivar differences, and/or treatment with 2,4-D. It is known that 2,4-D increases amino and amide nitrogen and prevents the production of certain amino acids from glucose (ALTMAN and DiTTMER, 1968).

The percentage of amino acids present in the nectar from plants sprayed with 2,4D did not vary consistently from that from untreated plants. Moreover, the overall quantity of nectar amino acids per flower increased in treated plants since spraying with $2,4-\mathrm{D}$ increased the volume of floral nectar by more than $30 \%$ in some cases (MOFFETT et al., 1980).

BuTLER et al. (1972) showed that the amounts and kinds of sugars in the floral nectar of cotton differ with species and time. Our work demonstrates that this is also the case with amino acids. Knowledge of these variations is important in synchrony of cultivation with insect pollinators.

Received for publication in August 1980.

\section{RÉSUMÉ}

Dans de nombreuses régions de culture du coton (Gossypium spp.), on considère cette plante comme étant d'un intérêt mellifère majeur. L'abeille (Apis mellifica) elle aussi est utile au cotonnier et c'est proba- 
blement l'insecte qu'on utilisera dans la plupart des cas pour polliniser les fleurs mâle-stérile dans la production de semences hybrides. Étant donnée l'importance du nectar floral dans l'attraction des abeilles vers les fleurs pour la pollinisation, nous avons analysé le nectar de trois variétés pour en déterminer les acides aminés. Nous avons également analysé du nectar de plants de cotonnier qui avaient été pulvérisés avec de l'herbicide 2,4-D à 4 concentrations différentes $(0,01 ; 0,1 ; 1,0$ et $10 \mathrm{ppm})$, puisqu'un travail précédent avait montré que le 2,4-D augmentait le volume du nectar floral.

Les échantillons de nectar ont été prélevés sur des fleurs de cotonnier qui avaient été ensachées au stade de bourgeon avancé le jour précédent. On a cultivé deux variétés (Deltapine 16 et Stoneville 213, lignée A) en un lieu et la troisième variété (Deltapine 61) en un autre endroit. Un analyseur d'acides aminés a été utilisé pour déterminer les acides aminés libres.

Seuls quatre acides aminés (acide aspartique, sérine, thréonine et acide glutamique) ont été trouvés dans le nectar de Deltapine 16 et de Stoneville 213 lignée A. Ces acides aminés sont également ceux qui prédominaient dans le nectar de Deltapine 61. Celui-ci renfermait pourtant 14 des 17 acides aminés détectables par les méthodes utilisées. Seules la cystine, la méthionine et la tyrosine en étaient absentes.

Les acides aminés du nectar provenant de plantes traitées avec différentes concéntrations de 2,4-D ont varié avec le temps et le traitement. Néanmoins la quantité globale d'acides aminés du nectar par fleur s'est accrue dans toutes les variétés traitées puisque le 2,4-D a augmenté le volume de nectar floral de plus de $30 \%$ dans certains cas.

\section{ZUSAMMENFASSUNG}

\section{AMINOSÄUREN IM BLÜTENNEKTAR DER BAUMWOLLE}

In vielen Gebieten, in denen man Baumwolle (Gossypium) anpflanzt, wird sie als wichtige Honigpflanze betrachtet. Die Honigbiene (Apis mellifera) ist auch für die Baumwolle von Nutzen, sie ist wahrscheinlich das einzige Insekt, das in den meisten Fällen dazu verwendet wird, den Pollen von den männlichen sterilen Blüten bei der Erzeugung von Baumwoll-Hybridsaat zu übertragen. Wegen der Bedeutung des Blütennektars für die Anlockung der Honigbienen zur Bestäubung der Blüten haben wir den Nektar von drei Zuchtsorten auf Aminosäuren üntersucht. Ausserdem haben-wir den Nektar von Baumwollpflanzen in die Untersuchung mit einbezogen, die mit dem Herbizid 2,4-D in vier Konzentrationen $(0,01,0,1,1,0$ und $10 \mathrm{ppm})$ behandelt worden waren, denn in früheren Versuchen hatte sich ergeben, dass 2,4-D die Menge des Blütennektars erhöht.

Aus Baumwollblüten, die am vorhergehenden Tag im späten Knospenstadium eingebeutelt worden waren, wurden Nektarproben gesammelt. Zwei Sorten (Deltapine 16 und A-line Stoneville 213) waren an einer Stelle angebaut, eine andere Sorte (Deltapine 61) an einer anderen Stelle. Zur Bestimmung der vorhandenen freien Aminosäuren wurde ein Aminosäuren-Analysator benutzt.

Nur vier Aminosäuren (Asparaginsäure, Serin, Threonin und Glutaminsäure) wurden im Nektar von Deltapine 16 und von A-line Stoneville 213 gefunden. Diese Aminosäuren waren auch im Nektar von Deltapine 61 vorherrschend. Aber der Nektar von dieser Sorte enthielt 14 von den 17 Aminosäuren, die mit der benutzten Technik nachgewiesen werden konnten. Nur Cystin, Methionin und Tyrosin waren nicht vorhanden.

Im Nektar von Pflanzen, die zweimal mit verschiedenen Konzentrationen von 2,4-D besprüht worden waren, schwankten die Aminosäuren sowohl mit der Zeit wie mit der Behandlungsart. Die Gesamtquantität der Aminosäuren im Nektar pro Blüte stieg jedoch bei den besprühten Sorten an, da 2,4$\mathrm{D}$ die Menge des Blütennektars in einigen Fällen um mehr als $30 \%$ steigerte.

\section{REFERENCES}

Altman P. L., Dittmer D. S. (ed.), 1968. - "Metabolism », 478-479, Federation of American Societies for Experimental Biology, Bethesda, Maryland. 
BAKER H. G., BAKER I., 1973 a. - Amino acids in nectar and their evolutionary significance. Nature, 241 : 543-545.

BAKER H. G., BAKER I., $1973 \mathrm{~b}$. - Some anthecological aspects of the evolution of nectar-producing flowers, particularly amino acid production in nectar. In "Taxonomy and Ecology", ed. V. H. Heywood, 243-264, Academic Press, New York.

BAKER H. G., BAKER I., 1975. - Studies of nectar-constitution and pollinator-plant coevolution. In * Coevolution of Animals and Plants „, ed. L. I. Gilbert and P. H. Raven, 100-140, University of Texas Press, Austin.

BAKER H. G., BAKER I., 1977. - Intraspecific constancy of floral nectar amino acid complements. Bot. Gaz., $138: 183-191$.

BaKer H. G., Opler P. A., BaKer I., 1978. - A comparison of the amino acid complements of floral and extrafloral nectars. Bot. Gaz., 139 : 322-332.

BAKER I., BAKER H. G., 1976 a. - Analyses of amino acids in flower nectars of hybrids and their parents, with phylogenetic implications. New Phytol., $76: 87-98$.

BaKer I., BaKer H. G., 1976 b. - Analysis of amino acids in nectar. Phytochem. Bull., 9 : 4-7.

Butler G. D., Jr., Loper G. M., McGregor S. E., Webster J. L., Margolis H., 1972. - Amounts and kinds of sugars in the nectars of cotton (Gossypium spp.) and the time of their secretion. Agron.J., $64: 364-368$.

Clark E. W., LuKefahr M. J., 1956. - A partial analysis of cotton extrafloral nectar and its approximation as a nutritional medium for adult pink bollworms. J. Econ. Entomol., 49 : 875-876.

Hanny B. W., Elmore C. D., 1974. - Amino acid composition of cotton nectar. Agr. Food Chem., 22 : 476-478.

KIRK P. L., 1950. - Kjeldahl method for total nitrogen. Anal. Chem., 22 : 354-358.

MCGREGor S. E., 1976. - Insect pollination of cultivated crop plants. U. S. Dept. Agric. Handbook, 496.

MEYER V. G., 1973. - A study of reciprocal hybrids between upland cotton (Gossypium hirsutum L.) and experimental lines with cytoplasms from seven other species. Crop Sci., $13: 439-444$.

MofFETt J. O., Stith L. S., Shipman C. W., 1978. - Effect of honey bee visits on boll set, seeds produced and yield of Pima cotton. 1978 Beltwide Cotton Res. Conf. Proc., 80-82.

Moffett J. O., Stith L. S., Burkhardt C. C., Shipman C. W., 1976. - Nectar secretion in cotton flowers and its relation to floral visits by honey bees. Amer. Bee. J., $116: 32,34,36$.

Moffett J. O., Stith L. S., Morton H. L., Shipman C. W., 1980. - Effect of cotton yield, floral nectar, seed germination, and honeybee visits. Crop Sci., 20:747-750.

Mound L. A., 1962. - Extrafloral nectaries of cotton and their secretions. Emp. Cotton Grow. Rev., 39 : 254-261.

Spackman D. H., 1963. - Accelerated system for the automatic analysis of amino acids. Fed. Proc., 22 : 244.

YоконамА V. Y., 1978. - Relation of seasonal changes in extrafloral nectar and foliar protein and arthropod populations in cotton. Environ. Entomol., 7 : 799-802. 